JURNAL SOSIAL-EKONOMI PERTANIAN DAN AGRIBISNIS

JOURNAL ON SOCIO-ECONOMICS OF AGRICULTURE AND AGRIBUSINESS

e-ISSN: $2615-6628$

p-ISSN: $1411-7176$

\title{
MENAKAR PERUBAHAN SOSIO-KULTURAL MASYARAKAT TANI AKIBAT MISKONSEPSI MODERNISASI PEMBANGUNAN PERTANIAN
}

Kadhung Prayoga, Suryani Nurfadillah, Manna Saragih dan Adietya Muhammad Riezky Program Studi Agribisnis, Departemen Pertanian, Fakultas Peternakan dan Pertanian, Universitas Diponegoro

E-mail: kadhungprayoga@gmail.com HP: 085731743929

\begin{abstract}
ABSTRAK
Revolusi hijau adalah bentuk nyata bagaimana modernisasi pertanian diartikan oleh pemerintah Indonesia. Sebuah program akselerasi pertanian yang bertujuan meningkatkan efektivitas kerja petani. Keberhasilannya pernah menjadikan Indonesia sebagai negara yang swasembada beras, meskipun begitu modernisasi pertanian ini meninggalkan banyak dosa yang menyebabkan perubahan dalam pola hidup masyarakat tani, baik dari sisi sosial maupun ekonomi. Modernisasi pertanian justru menimbulkan langkah mundur dalam pembangunan pertanian karena kesalahan pemerintah dalam mengartikan modernisasi itu sendiri. Alasan inilah yang kemudian melatarbelakangi penulisan paper ini yang ingin menjelaskan secara detail perubahan sosial ekonomi apa saja yang sebenarnya terjadi karena kesalahan mengartikan modernisasi.Pendekatan yang digunakan dalam menuliskan hasil penelitian ini adalah pendekatan kualitatif dengan menggunakan metode deskriptif. Teknik pengumpulan data menggunakan metode studi pustaka untuk mendapatkan data-data sekunder. Analisis menggunakan interpretasi peneliti dengan mengacu pada berbagai literatur. Hasilnya adalah banyak terjadi perubahan sosial budaya bahkan hingga ekonomi di struktur kehidupan masyarakat desa. Banyak wanita tani yang kehilangan pekerjaan dan termarginalisasi, tidak ada lagi pembagian kerja berdasarkan gender, kencangnya laju urbanisasi, lambatnya regenerasi, ketergantungan terhadap industri, musnahnya plasma nutfah, hilangnya budaya gotong royong, lahirnya sistem kasta dalam masyarakat tani, melemahnya fungsi kelembagaan lokal, petani hanya sebagai objek penyuluhan, dan banyak lainnya. Oleh karena itu, kedepan modernisasi pertanian harus berbasis pada komunitas tani dan meletakkan perspektif pembangunan pedesaan secara utuh berbasis pendekatan pemberdayaan.
\end{abstract}

Kata kunci: modernisasi, revolusi hijau, perubahan sosial ekonomi dan pembangunan pertanian 


\title{
MEASURING SOCIO-CULTURAL CHANGES IN FARMERS SOCIETY AS A RESULT OF MISCONCEPTIONS ON MODERNIZATION OF AGRICULTURAL DEVELOPMENT
}

\begin{abstract}
The green revolution is an evidence of how agricultural modernization was interpreted by the Indonesian government. An agricultural acceleration program that aimed to improve the effectiveness of farmers' work. Its success has made Indonesia a self-sufficient country for rice, however, this modernization of agriculture has left many sins that have caused changes in the lives of farmers, both socially and economically. The modernization of agriculture actually led to a step backward in agricultural development because of the government's mistake in interpreting modernization itself. The purpose of this paper was to explain in detail what socioeconomic changes that actually occur because of errors in interpreting modernization. The approach used in this study is a qualitative approach using descriptive methods. This study used literature study method to obtain secondary data and the interpretation reference to various literature was used to analyse the data. The analysis led to result that there have been many socio-cultural and economic changes in the structure of life of the village community. Many women lose their job as a farmer and they were marginalized, there was no division of labor based on gender, rapid and unplanned urban growth, stagnant regeneration, overdependence on industry,germplasm destruction, mutual cooperation culture degradation, caste system emergence in farming communities, the weakening of local institutional functions, farmer was only as an extension object, and others. In the future, agricultural modernization must be based on the peasant community and put the whole rural development perspective based on the empowerment approach.
\end{abstract}

Keywords:agricultural development, green revolution, modernization and socioeconomic change

\section{PENDAHULUAN}

Kebijakan pembangunan di suatu negara tidak akan lepas dari efek samping yang ditimbulkan. Ketika suatu negara memilih kebijakan untuk diimplementasikan pasti akan berpengaruh terhadap perubahan tatanan sistem dan tatanan sosial. Hingga pada akhirnya juga akan berpengaruh terhadap perubahan perilaku masyarakat yang melaksanakan perubahan sistem tersebut. Salah satu kebijakan yang diambil pemerintah adalah modernisasi pertanian guna mendukung sebuah pembangunan di sektor pertanian. Kebijakan itu terkenal dengan nama revolusi hijau.

Revolusi hijau adalah bentuk nyata bagaimana modernisasi pertanian diartikan oleh pemerintah Indonesia. Sebuah pembaharuan yang menjelma dalam diri sebuah program yang bertujuan melakukan akselerasi produksi hasil pertanian dengan mengubah cara bertani masyarakat lewat rekayasa teknologi mulai dari pupuk, cara pemberantasan hama, pengaturan irigasi, pengolahan tanah, penggunaan alat mesin pertanian, hingga benih unggul. Semua upaya ini berkaca pada definisi modernisasi yang menurut Stompka (2007) adalah transformasi total masyarakat tradisional atau pra-modern ke tipe masyarakat teknologi dan organisasi sosial yang menyerupai kemajuan dunia barat yang ekonominya makmur dan situasi politiknya stabil. 
Modernisasi pertanian perlu dilakukan karena bisa meningkatkan efektivitas kerja petani.Modernisasi tercermin dalam sendi-sendi kehidupan masyarakat, modernisasi bukanlah menjadi suatu hal asing atau baru, tetapi modernisasi adalah sesuatu yang sedang berlangsung dan akan terus berlangsung sepanjang manusia masih hidup, hal ini disebabkan karena ilmu pengetahuan dan teknologi terus berkembang dan menciptakan inovasi-inovasi baru (Djoh, 2018). Namun, alangkah baiknya apabila kita dapat memahami serta mengkritisi dampak serta keuntungan dari inovasi-inovasi baru tersebut.

Untuk mendukung tercapainya modernisasi pertanian, maka pemerintah memilih untuk melakukan kegiatan penyuluhan secara masif kepada petani dan represif lewat TNI. Sistem penyuluhan top down dirasa efektif pada masa itu karena petani dianggap sebagai individu yang kosong tanpa pengetahuan dan butuh dididik oleh penyuluh. Pada masa itu, semua kegiatan penyuluhan mulai dari perencanaan hingga evaluasi sudah ditentukan pemerintah dan petani tinggal menjalankan kebijakannya saja. Petani adalah subjek penyuluhan yang harus menuruti penyuluh sebagai ujung tombak pemerintah dalam menyukseskan program revolusi hijau. Bukannya tanpa hasil, upaya ini telah terbukti membawa Indonesia swasembada.

Terbukti, Indonesia menjadi negara pengimpor beras terbesar di dunia pada akhir tahun 1960an hingga 1970an. Kemudian pada tahun 1985, Indonesia telah mencapai technical self sufficiency pada komoditi beras yang berarti memiliki mampu memenuhi kebutuhan dalam negeri tanpa bantuan dari luar, bahkan saat itu Indonesia juga memiliki cadangan 2 juta ton beras. Meskipun tidak mengekspor, Indonesia terlibat dalam pemberian pinjaman beras ke Vietnam dan Filipina. Di awal program intensifikasi beras, produksi rata-rata sekitar 11 juta ton beras giling. Kemudian pada pertengahan tahun 1980an produksinya meningkat lebih dari dua kali lipat menjadi 25 juta ton, dan pada tahun 1898 mencapai 30 juta ton. Tidak hanya unggul dalam perberasan, di akhir tahun 1980an, Indonesia telah menjadi produsen utama dan eksportir pupuk urea yang mampu menghasilkan lebih dari 5 juta ton urea setiap tahunnya. Indonesia juga memproduksi lebih dari satu juta ton triple super fosfat dan 650 juta ton ammonium sulfat (FAO 2011; Stads et al.2007; Thirtleet al.2013)

Cita-cita untuk menjadi negara yang swasembada beras secara tidak langsung turut menyumbang perbaikan infrastuktur di Indonesia. Sistem irigasi, khususnya di Jawa, telah mengalami rehabilitasi dan peningkatan yang substansial. Selain itu Indonesia juga berinvestasi besar terhadap pengembangan industri benih dan pupuk, jaringan transportasi, dan sistem pergudangan nasional untuk melancarkan pendistribusian input maupun output. Fasilitias penelitian dengan stasiun eksperimental juga dibangun di berbagai wilayah dalam rangka menyediakan pengetahuan yang dibutuhkan untuk mengadaptasi teknologi dan memantau perkembangannya. Pemerintah juga membangun sistem perbankan pedesaan untuk menyalurkan kredit kepada petani supaya mereka dapat 
mengadopsi input dan teknologi yang diprogramkan secara nasional. Lebih dari 5.000 jaringan bank pedesaan yang telah dimulai dengan memberikan kredit bersubsidi untuk beras, dan pada 1980-an telah berkembang menjadi lembaga yang menawarkan kredit pedesaan umum dan rencana tabungan pedesaan yang menarik masyarakat (Thirtleet al.2013; Wiket al. 2008).

Meskipun mampu mencapai kondisi swasembada pangan dan sukses dalam pembangunan infrastruktur, ternyata revolusi hijau meninggalkan banyak dosa di sektor pertanian. Revolusi hijau justru menyebabkan Indonesia menjadi importir beras tertinggi di dunia. Selepas swasembada pangan, perlahan namun pasti produksi pertanian di Indonesia semakin turun, lahan yang tidak lagi subur, hilangnya plasma nutfah, hingga tidak ada lagi warga desa yang mau menjadi petani. Dalam penelitian Elizabeth (2007), penerapan paradigma modernisasi dalam pelaksanaan pembangunan pertanian menyebabkan terjadinya perubahan struktur sosial masyarakat petani di pedesaan. Perubahan yang terjadi meliputi struktur pemilikan lahan pertanian, pola hubungan kerja dan struktur kesempatan kerja, serta struktur pendapatan petani di pedesaan.

Miskonsepsi dalam mengimplementasikan modernisasi tidak hanya berdampak pada sektor lingkungan, namun telah ikut andil dalam merubah aspek sosial budaya dan ekonomi masyarakat perdesaan. Kesalahan dalam mengartikan modernisasi justru menyebabkan banyak petani kehilangan jati dirinya sebagai bagian integral masyarakat desa. Bahkan kegiatan penyuluhan yang top down telah membuat petani kehilangan kreativitas, ketergantungan dan menyumbang pemikiran munculnya konsep pemiskinan wanita di perdesaan. Sekarang, juga sudah menjadi hal yang jamak ketika negara yang mengklaim dirinya sebagai negara pertanian justru menjadi negara terdepan yang melakukan impor pangan. Bahkan ancaman ketiadaan petani muda juga menjadi suatu tantangan. Senada dengan hal ini Usman (2015) mengidentifikasi pengaruh negatif modernisasi pertanian adalah munculnya masalah mengenai kerusakan lingkungan, masalah hak asasi petani, dan melemahnya fungsi institusi lokal. Tahir (2009) juga melihat dampak lain modernisasi adalah terjadi perubahan pola bertani subsiten ke komersil serta adanya pembagian kerja yang terspesialisasi. Banyaknya perubahan sosial ekonomi yang terjadi karena modernisasi menyebabkan lahirnya penulisan paper ini. Paper yang bertujuan untuk menjelaskan secara detail perubahan sosial ekonomi apa saja yang sebenarnya terjadi karena kesalahan mengartikan modernisasi.

\section{METODE PENELITIAN}

Pendekatan yang digunakan dalam menuliskan hasil penelitian ini adalah pendekatan kualitatif dengan menggunakan metode deskriptif. Teknik pengumpulan datanya sendiri menggunakan metode studi pustaka untuk mendapatkan data-data sekunder. Data sekunder yang digunakan berasal dari bahan-bahan tertulis seperti penelitian terdahulu, jurnal, buku, tesis, disertasi, dan berbagai informasi digital yang ada di 
internet. Analisis menggunakan interpretasi peneliti dengan mengacu pada berbagai literatur atau referensi yang relevan dengan objek kajian. Langkah pertama ialah pengumpulan berbagai data sekunder berupa hasil penelitian seperti skripsi, tesis, jurnal, disertasi, maupun buku-buku mengenai revolusi hijau dan modernisasi. Kemudian data sekunder tersebut dipelajari, diringkas, serta disusun menjadi sebuah ringkasan studi pustaka yang relevan. Selanjutnya dilakukan sintesis dan analisis dari hasil ringkasan studi pustaka. Terakhir ialah penarikan hubungan dari semua data yang telah diinterpretasikan.

\section{HASIL DAN PEMBAHASAN}

\section{Modernisasi Pertanian: Sebuah Kesalahan Cara Pandang}

Sejatinya menurut Pranadji (2000), modernisasi pertanian adalah suatu perubahan pengelolaan usahatani dari tradisional ke pertanian yang lebih maju dengan penggunaan teknologi-teknologi baru. Dalam arti yang lebih luas, transformasi tidak hanya mencakup perubahan yang terjadi pada bentuk luar, namun pada hakikatnya meliputi bentuk dasar, fungsi, struktur, atau karakteristik suatu kegiatan usaha ekonomi masyarakat. Namun, ketika berbicara mengenai modernisasi di sektor pertanian maka yang perlu mendapat banyak sorotan adalah manusia yang merumuskan program sebagai hasil sintesis dari konsep modernisasi. Konsep dari modernisasi tidak pernah salah, yang salah adalah bagaimana para pemangku kebijakan mengartikan modernisasi tersebut. Para pemangku kebijakan yang menelurkan embrio revolusi hijau hanya memandang modernisasi sebagai sebuah jalan untuk mengubah apa yang dianggap tradisional menjadi modern. Tetapi tidak memperhatikan dampak yang akan terjadi di masa yang akan datang.

Kesalahan-kesalahan dalam menerjemahkan modernisasi beserta penyuluhan sebagai tool untuk mencapai modernisasi inilah yang justru menyebabkan modernisasi bergerak ke arah yang berlawanan dengan apa yang dicita-citakan. Bahkan dampaknya hingga hari inipun masih terasa, mulai dari aspek lingkungan, ekonomi, sosial, hingga budaya pertanian. Pretty (1995) juga melihat pendekatan modernisasi seringkali mengabaikan aspek keberlanjutan, kecenderungan antipoor dan bias urban. Bahkan disitasi dari Hendrastomo (2011) revolusi hijau adalah suatu revolusi kebudayaan dan menjadi lompatan besar sebelum menuju masyarakat industri. Pada fase ini, walaupun masih berbasis pada pertanian, tetapi mulai diperkenalkan teknologi yang dipergunakan sebagai rekayasa alam, sehingga pertanian tradisional yang umumnya bergantung pada alam cepat berubah menjadi pertanian berbasis industri. Namun, ada sedikit lompatan dimana fondasi kita pada fase pertanian belum kokoh benar tetapi langsung diperkenalkan dengan industri. Percepatan perkembangan inilah yang dikemudian hari justru memunculkan banyak persoalan dalam masyarakat.

Miskonsepsi ini melahirkan banyak kerugian bagi petani. Kerugian yang kini sudah sangat sulit untuk diperbaiki. Suseno dan Suyatna (2007) menjelaskan bahwa penentuan varietas padi oleh pemerintah 
menyebabkan ketergantungan petani pada bibit unggul yang seragam sehingga meninggalkan bibit lokal yang dimiliki, subsektor tanaman pangan rentan terhadap berbagai hama, petani menjadi bodoh dengan melupakan banyak pengetahuan lokal dan menggantungkan diri pada paketpaket teknologi produk industri. Revolusi hijau yang diterapkan oleh pemerintah juga telah menghancurkan keragaman hayati di lahan pertanian yang menjadi sumber pangan bagi masyarakat dan petani tradisional. Hilangnya keberagaman sumber pangan menjadikan padi hasil revolusi hijau menjadi satu-satunya sumber pangan. Ketergantungan pada satu sumber pangan (beras) menjadikan semakin rentannya ketahanan pangan dalam masyarakat petani.

\section{Menelaah Perubahan Sosial Budaya Masyarakat Tani Sebagai Akibat Miskonsepsi Modernisasi Pertanian}

Masyarakat dan kebudayaan manusia di mana pun dan kapan pun selalu mengalami perubahan. Perubahan-perubahan yang terjadi dapat berjalan lambat dan dapat pula berjalan cepat. Merunut pada pendapat Mulyadi (2015), perubahan itu ada untuk memenuhi kebutuhan manusia yang semakin kompleks. Semua berawal dari sifat manusia yang selalu menginginkan sesuatu yang lebih baik. Kebutuhankebutuhan hidup itu tentu saja harus diusahakan dengan menggunakan cara-cara dan upaya-upaya tertentu. Namun, keterbatasan sumber daya terkadang menjadi limitasi. Keterbatasan sumber-sumber inilah yang menyebabkan manusia mulai berpikir, bagaimana cara untuk mendapatkan kebutuhan-kebutuhan itu. Salah satunya adalah dengan menciptakan suatu sistem yang dikenal sebagai modernisasi. Modernisasi dapat diartikan sebagai transformasi yaitu perubahan. Perubahan yang terjadi di tengahtengah masyarakat dalam segala aspek.

Program pembangunan dan modernisasi pertanian, dalam pandangan Tjondronegoro (1999) merupakan salah satu strategi yang diterapkan pemerintah untuk menimbulkan perubahan sosial di perdesaan Jawa. Perubahan sosial merupakan suatu perbedaan yang terjadi di tengah-tengah kehidupan masyarakat dari waktu ke waktu. Perubahan sosial dapat terjadi sebagai akibat konflik, adanya elit kreatif, cara berpikir baru, kekuatan dari luar, motivasiindividu untuk berprestasi, dan sejumlah penyebab lain (Lauer, 2001). Perlu disadari pula bahwa perubahan-perubahan sosial yang lahir dari modernisasi tidak selamanya memberikan efek yang baik. Oleh karena itu perlu kesiapan diri untuk mengantisipasi perubahan-perubahan sosial yang terjadi.

\section{Semakin Termarginalisasinya Kaum Perempuan}

Lan (2015) memandang implementasi modernisasi pertanian melalui program revolusi hijau tersebut dianggap telah merusak tatanan masyarakat perdesaan, khususnya terkait dengan apa yang disebut sebagai hubungan kesetaraan gender. Sebelum modernisasi pertanian diintrodusir ke tengah masyarakat perdesaan pola hubungan antara laki-laki dan perempuan bersifat hubungan kesetaraan gender atau keseimbangan gender, tetapi setelah modernisasi diterapkan maka 
dalam perspektif sosiologis hubungan struktural berubah menjadi ketimpangan gender. Artinya adanya hubungan dominasi dan subordinasi antara laki-laki dan perempuandidalam setiap aktivitas kehidupan masyarakat termasuk dalam aktivitas pertanian.TAP MPR No.IV/MPR/1999 tentang GBHN di dalam Bab IV tertera hal kebijakan pembangunan nasional dalam bidang sosial dan budaya salah satunya adalah kedudukan dan peranan perempuan. Beranjak dari itu telah terbukti bahwa isu wanita masih menjadi sorotan penting dalam pembangunan. Pembangunan selama ini telah banyak menimbulkan masalah baru di kalangan perempuan. Khususnya pada kelompok perempuan tani di perdesaan. Mereka dirugikan dari sisi kedudukan dan peranan. Wanita tani dari yang awalnya diikutsertakan dalam semua tahapan proses bertani lambat laun mulai digantikan oleh teknologi. Teknologi yang mensyaratkan spesialisasi keterampilan cenderung tidak bisa dioperasikan oleh wanita tani. Akibatnya wanita tani hanya mengerjakan pekerjaan yang sederhana dan tidak lagi berperan secara sentral. Pembangunan yang berhasil adalah pembangunan yang dapat mengintegrasikan wanita pada setiap iramanya bukan malah mencampakkan mereka. Kenyataan yang senada juga dikemukakan oleh Fakih (1999) bahwa pembangunan di Jawa telah menimbulkan marginalisasi perempuan atau telah memiskinkan kaum perempuan.

Perubahan-perubahan sosial wanita tani akibat dari modernisasi adalah dengan diperkenalkannya mesin-mesin,seperti mesin penuai dan traktor tangan yang telah menghilangkan mata pencaharian penduduk yang selama ini mendapatkan upah dari menuai (Ismanto et. al., 2012). Lebih lanjut Lan (2015)menjelaskan bahwa perempuan tidak lagi terlibat secara penuh dalam bidang pertanian, karena ada penilaian bahwa perempuan tidak bisa menangani mesin pertanian. Hal ini menyebabkan pemilik tanah memutuskan hubungan dengan pekerja. Putusnya hubungan antara pemilik tanah dan para pekerja membuat perbedaan antara kelas kaya dan miskin semakin nyata (Scott, 2000).

Contoh nyata ditunjukkan dari penelitian Ismanto et. al. (2012) terkait modernisasi pertanian yang terjadi di Mranggen. Di tempat ini terdapat penggunaan alat-alat pertanian yang menggunakan mesin, seperti traktor yang telah menggantikan kerbau sebagai alat bajak. Sehingga para pemilik kerbau tidak bisa lagi mendapat upah dari membajak sawah dan beralih profesi. Demikian halnya para pemetik padi, biasanya padi dipetik oleh para ibu-ibu, karena adanya perontok padi yang bermesin maka pekerjaan tersebut cukup dikerjakan oleh sedikit orang saja.Sehingga sebagian ibu-ibu juga kehilangan pekerjaannya sebagai pemetik padi.Dari kenyataan itu jelas terbukti bahwa modernisasi sebagai perspektif pembangunan di negara ini membawa akibat yang fatal. Khususnya bagi perempuan pedesaan yang bekerja di sektor pertanian. Kondisi ini menurut Elizabeth (2007) menimbulkan terjadinya gejala disintegrasi dan diskriminasi dalam pembagian kerja antara pria dan wanita di berbagai bidang. 
Kesalahan konsepsi pembangunan yang hanya diartikan sekedar pembangunan infrastruktur dan mekanisasi pertanian menyebabkan tenaga manusia mulai tergantikan oleh mesin. Pemanenan yang dulunya dilakukan oleh wanita tani kini sudah digantikan oleh mesinmesin tersebut. Inovasi penggunaan teknologi mesin tersebut memang dapat menjamin peningkatan hasil produksi para petani. Namun, petani juga mengerti bahwa apabila inovasi teknologi tersebut gagal, para petanilah yang harus menanggung risikonya. Penggunaan traktor dan mesin pertanian yang mensyaratkan kualifikasi tertentu juga semakin mendiskreditkan wanita tani serta masyarakat desa lain yang tidak memiliki keahlian. Apalagi alat mesin pertanian memang tidak dirancang untuk wanita. Proses modernisasi pertanian telah menimbulkan dampak dalam meningkatkan pengangguran bagi kelompok perempuan karena tidak adanya akses untuk memanfaatkan teknologi baru dan meningkatnya spesialisasi mata pencaharian.Perempuan tidak lagi terlibat secara penuh dalam bidang pertanian, karena ada penilaian bahwa perempuan tidak bisa menangani mesin pertanian.Dengan kata lain, partisipasi tradisional perempuan sebagai pekerja di sawah menjadi tersingkir karena persyaratan teknis yang obyektif dari metode yang baru.

Hal ini diteguhkan oleh Soetrisno (1990) yang menjelaskan bahwa kenaikan produksi pertanian karena revolusi hijau tidak diikuti dengan pengorbanan kaum wanita pedesaan, khususnya mereka yang miskin yang harus kehilangan mata pencaharian mereka. Kaum wanita miskin terpaksa tidak dapat mengikuti peristiwa panen di desa mereka secara bebas karena para pemilik sawah membatasi jumlah wanita miskin yang diijinkan ikut panen di sawah mereka. Akibatnya wanita tani yang miskin juga kehilangan sumber bahan pangan yang murah. Ketika terjadi perubahan teknologi panen dari aniani ke teknologi sabit, maka sekali lagi kelompok wanita miskin terpaksa menyingkir dan tempatnya digantikan oleh buruh tani pria. Demikian pula ketika terjadi perubahan teknologi huller maka ratusan bahkan mungkin ribuan wanita miskin di pedesaan yang bermata pencaharian penumbuk padi akhirnya terpaksa menganggur. Rendahnya kesempatan bekerja wanita tani baik sebagai buruh tani maupun menjadi pemanen ini menyebabkan penghasilan dan kesejahteraannya semakin rendah. Akibatnya jurang pemisah antara wanita yang menjadi buruh tani dan yang kaya juga semakin lebar.

Ditambah lagi dengan minimnya keterampilan dan pendidikan yang mereka miliki membuat banyak perempuan dari perdesaan pergi ke kota menjadi buruh-buruh murah atau pekerja seks komersial. Penelitian Nurpilihan et. al. (2000) bahkan menunjukkan suatu hasil bahwa wanita tani di desa yang hanya berpendidikan SD mengakui bahwa mereka banyak kehilangan perkerjaan akibatmasuknya modernisasi pertanian. Wanita tani kemudian menjadi terusir dari desa.Terdamparnya mereka di kota telah menambah jumlah orang miskin perkotaan. Inilah yang dikenal dengan konsep pemiskinan perempuan. Keteledoran tersebut menyebabkan 
posisi kaum wanita makin terjepit dan terkungkung dalam dimensi keterbatasan. Secara internal, keterbatasan wanita tercermin pada lebih rendahnya pendidikan, keterampilan, rasa percaya akan kemampuan dan potensi diri. Secara eksternal, keterbatasan tersebut tercermin pada lebih rendahnya akses wanita menangkap berbagai peluang di luar rumah tangganya.

Satu-satunya pilihan yang ada bagi wanita tani adalah harus berkutat di sektor non pertanian. Bekerja di sektor pertanian kemudian tidak lagi dianggap sebagai sesuatu yang menjanjikan. Munculnya anggapan bahwa sektor pertanian tak lagi menjadi lahan basah juga menjadikan wanita tani semakin enggan untuk bekerja di sektor pertanian. Ditambah lagi dengan gengsi ketika harus bekerja di sektor pertanian karena selama ini menjadi petani identik dengan menjadi miskin. Akibatnya, hingga hari ini sangat jarang ditemui pemuda desa yang mau menjadi petani. Pemuda desa akan lebih memilih untuk bekerja di sektor non pertanian karena dirasa lebih memberikan kontribusi pendapatan yang tinggi. Geertz dalam Husken (1988) bahkan mengajukan asumsi bahwa modernisasi pertanian hanya akan membawa kelumpuhan yang lebih parah pada ekonomi pedesaan di Indonesia. Jadi, revolusi hijau hanya menguntungkan petani kaya sedangkan petani kecil, wanita tani, dan buruh tani terdesak keluar sektor pertanian dan terpaksa mencari nafkah di sektor informal di perkotaan. Terjadilah kemudian yang disebut dengan transformasi ekonomi pedesaan.

\section{Hilangnya Budaya Sambatan}

Perubahan sosial lain yang disebabkan oleh revolusi hijau adalah hilangnya budaya gotong royong di masyarakat perdesaan. Jauh sebelum adanya industri masyarakat sangat menjunjung tinggi kerukunan diantara sesama warga,maka setelah masuknya industri ke daerah desa sedikit mengalami pergeseran terutama dalam hal gotong-royong. Sistem kekeluargaan yang ada sedikit merenggang. Tolong menolong dalam membantu warga sekarang dilakukan hanya pada komunitas tertentu saja. (Ismanto et. al., 2012).

Sebelum era revolusi hijau banyak ditemui budaya sambatan yang mana masyarakat termasuk di dalamnya adalah wanita tani saling membantu karena mereka saling peduli dan dalam kegiatan sambatan tidak menuntut untuk mempunyai keahlian tertentu yang terpenting adalah kebersamaan dan solidaritas pada masyarakat. Tetapi dengan adanya modernisasi pertanian telah merubah perilaku masyarakat menjadi lebih materialistis dan mengharapkan sistem upah karena modernisasi mensyaratkankeahlian tertentu. Koentjaraningrat (2000) juga menyebutkan tolong menolong dalam pertanian mulai terkikis oleh adanya budaya padat karya dengan sistem upah, sedang pola hidup tolong menolong diganti dengan pola kerja pamrih.

Modernisasi pertanian yang
mensyaratkan keahlian dalam
pengelolaan lahan pertanian juga
menyebabkan masyarakat lebih
percaya kepada tenaga ahli dan tidak
lagi percaya pada usaha-usaha
kolektif seperti sambatan. Muncul
suatu label bahwa perkerjaan yang


ditangani oleh jasa tenaga ahli akan lebih baik jika dibandingkan dengan tenaga sambatan yang hanya menggunakan kemampuan sebisanya. Anggapan lebih baik menggunakan tenaga ahli menggeser peran sambatan dalam masyarakat untuk beralih menggunakan tenaga ahli yang lebih praktis dan cepat. Hal ini juga karena tenaga sambatan tidak dapat mengerjakan pekerjaan yang bersifat khusus dan membutuhkan penanganan yang teliti, sehingga sifat kerja sambatan pada jaman sekarang tidak lebih sebagai pembantu tenaga ahli, karena hal yang bersifat khusus dan membutuhkan penanganan teliti harus diambil alih oleh tenaga ahli. Hilangnya sambatan juga menyebabkan hilangnya kesempatan wanita tani untuk berperan dalam kegiatan masyarakat.

Hilangnya budaya sambatan juga menunjukkan gejala bergesernya pola hidup masyarakat desa dari yang awalnya komunal berubah menjadi individual. Masyarakat tani sebelum adanya penerapan modernisasi pertanian cenderung lebih bersifat sosialis, artinya rasa kekeluargaan yang terbangun antara petani dan petani lainnya masih ada, sedangkan setelah adanya penerapan modernisasi pertanian lebih bersifat individualistis atau menghilangnya rasa kekeluargaan yang pernah terbangun dengan sesama petani. Sistem komunal yang ditunjukkan dengan kegiatan saling bantu dan gotong royong berevolusi menjadi sistem kapitalis yang lebih mengedepankan modal dan berorientasi produksi. Para petani perdesaan termasuk wanita tani yang pada umumnya menganut teguh moral ekonomi sebagai prinsip hidup dan memegang erat tradisi komunal kemudian berubah pendiriannya menjadi berpihak kepada ekonomi rasional.

\section{Lahirnya Sistem Pengkastaan}

Akibat lain yang ditimbulkan adalah munculnya sistem pengkastaan, padahal sebelum adanya modernisasi masyarakat tani tidak mengenal adanya sistem stratifikasi. Adapun, itu hanya ditentukan berdasarkan siapa yang mengumpulkan hasil ladang terbanyak. Pandangan inipun bergeser dengan lahirnya konsep modernisasi, modernisasi menyebabkan munculnya dua kutub besar dalam masyarakat tani yaitu tuan tanah atau petani dengan lahan luas dan petani gurem atau buruh tani. Tuan tanah menundukkan buruh tani, buruh tani ada hanya untuk memenuhi kebutuhan tuan tanah. Buruh tani bukan berperan sebagai mitra, tapi hanya sebagai penyedia tenaga kerja bagi petani yang kaya. Hasil subordinasi dan proses eksploitasi ini bahkan masih bisa dilihat hingga hari ini.

Setidaknya muncul dua kutub pengkastaan yaitu petani lapis atas dan petani lapis bawah. Petani lapisan atas merupakan petani yang memiliki akses pada sumberdaya lahan, kapital,mampu merespon teknologi dan pasar denganbaik, serta memiliki peluang berproduksi yang berorientasi keuntungan. Petani lapisan bawah lebih kepada golongan mayoritas di pedesaan yang merupakan petani yang relatif miskin, lahan yang sempit, hingga modal yang terbatas.

Modernisasi

juga

memunculkan pelapisan dalam masyarakat, sehingga lahirlah konsep patron dan klien. Klien akan selalu 
tunduk kepada patron dan patron merasa memiliki kehidupan klien. Sebisa mungkin patron akan mengikat klien agar selalu berhubungan kerja dengannya. Konsep ini menimbulkan ketergantungan klien terhadap patron. Patron disini biasanya adalah petani kaya atau petani dengan lahan yang luas. Sementara itu klien lebih kepada petani miskin dan petani gurem. Akibatnya adalah terjadi polarisasi, yang kaya semakin kaya dan yang miskin semakin tidak ada kesempatan untuk memperbaiki taraf hidupnya (Kandar, 2014). Kedua lapisan masyarakat petani tersebut terlibat dalam hubungan kerja yang kurang seimbang.

Sistem patron klien menurut Widodo (2009) mengukuhkan suatu fenomena bahwa petani kecil sebagai kelompok mayoritas harus mengakui kekalahan terhadap kaum pemilik modal yang notabene adalah minoritas. Dikuatkan oleh penelitian Rifkian et. al. (2017) yang menyebutkan dominasi patron menjadi sangat kentara setelah era revolusi hijau, buktinya adalah perekrutan tenaga kerja dilihat dari hasil kerja, pencarian tenaga kerja dilakukan langsung oleh pemilik, dan sistem pembagian hasil berupa uang (bayar langsung setelah bekerja).

\section{Melemahnya Fungsi Kelembagaan Lokal}

Di tingkatan yang paling rendah, pemerintah membentuk kelompok tani umtuk memudahkan koordinasi dan penyamaan persepsiantara pemerintah dengan petani. Tujuannya tentu agar petani bisa mendukung tujuan pemerintah tanpa adanya interupsi. Kelompok tani dibuat berdasarkan kepentingan pemerintah, bukanlah inisiatif eptani.
Akibatnya petani hanya menjadi pihak yang pasif dan tidak memiliki kuasa untuk mengambil keputusan sendiri. Pemerintah sudah akan memutuskan apa saja yang akan dilakukan petani, mulai dari jenis benih yang akan ditanam, hingga jenis pupuk yang digunakan. Petani tidak lagi memiliki power terhadap dirinya sendiri. Hal senada juga diungkapkan Tjondronegoro (1999) bahwa revolusi hijau telah menyebabkan rusaknya struktur pengorganisasian petani dan timbulnya pelapisan sosial.

Usman (2004) juga melihat adanya masalah melemahnya fungsi institusi lokal dalam praktik revolusi hijau. Dengan kebijakan sentralisasi pembangunan pertanian, institusiinstitusi lokal selama ini menjadi tidur dan tidak berfungsi. Petani diwajibkan terhimpun dalam kelompok tani yang dibentuk dan dikontrol oleh pemerintah. Petani dibiasakan bekerja dengan petunjuk yang diinstruksikan dari atas dan hampir tidak memiliki peluang terlibat dalam proses pengambilan keputusan yang menyangkut kehidupan mereka. Di sektor kelembagaan seperti kelompok tani yang juga banyak terjadi adalah ketua kelompok tani dipilih lebih berdasarkan status sosial. Posisi ketua kelompok tani di desa banyak diisi oleh petani dengan luasan lahan yang luas. Bukan karena kompetensinya namun lebih dikarenakan status sosialnya.

Lembaga lain seperti Bulog menurut Suseno dan Suyatna (2007) yang didirikan untuk mengontrol produk-produk pertanian dan membuat standarisasi harga bagi produk pertanian justru berubahmenjadi lembaga yang sangat profit oriented dan monopolistic yang 
hanya memberi peluang menguntungkan bagi sebagian kecil kelompok orang dan pada saat yang bersamaan, ada pihak lain yang dirugikan dalam jumlah yang sangat besar. Intervensi pemerintah dalam mengontrol harga gabah ini menyebabkan pendapatan petani tidak pernah meningkat.

Suseno dan Suyatna (2007) juga menyotori kinerja KUD (Koperasi Unit Desa) yang diharapkan berfungsi sebagai wadah kelompok tani ternyata kurang berjalan secara optimal. Dalam kenyataannya, KUD lebih bersifat sebagai suatu badan usaha yang anggota dan pengurusnya cenderung eksklusif dantidak mewadahi kelompok tani.

\section{Petani Hanya Sebagai Objek Penyuluhan}

Kesalahan

mengartikan

modernisasi lewat revolusi hijau bahkan telah menyentuh sektor penyuluhan. Semua kegiatan penyuluhan mulai dari perencanaan, penentuan materi dan metode, hingga evaluasi semua ditentukan oleh pemerintah pusat. Pemerintah daerah tidak memiliki kewenangan untuk mengelola daerahnya sendiri. Masyarakat juga tidak diikutsertakan dalam kegiatan penyuluhan. Selama revolusi hijau berlangsung, masyarakat tani (apalagi wanita tani) hanyalah objek pembangunan yang bodoh sehingga perlu penyuluhan. Masyarakat tidak pernah dilihat sebagai subjek pembangunan pertanian sehingga tingkat partisipasi terhadap pengembangan sektor pertanian juga rendah. Jadi, penyuluh hanya bekerja sebatas sebagai penyampai pesan pemerintah dan tidak memberikan serta menyediakan jasa yang memadai bagi petani.
Dengan sistem penyuluhan yang top down, penyuluhan sama sekali tidak digunakan untuk merubah pengetahuan petani, namun dengan tindakan yang represif penyuluhan hanya hadir untuk merubah perilaku petani tanpa memberikan alasan mengapa mereka harus merubah perilaku berusaha taninya. Akibatnya petani terbungkam suaranya dan tidak pernah diikutkan dalam proses pembangunan karena hanya dianggap sebagai kelompok marginal. Penyuluhan bukan semata memberi saja kepada masyarakat tani namun secara hakiki penyuluhan adalah proses untuk mengubah pola pikir masyarakat agar bisa menentukan apa yang sebenarnya baik bagi diri mereka. Sekilas sistem yang terpusat seperti ini pada dasarnya akan menguntungkan dan mempermudah masyarakat tani. Namun, karena tujuannya bukan untuk memajukan rational thinking dari masyarakat tani maka dampak yang dihasilkan pun justru merugikan mereka dalam jangka panjang.Jadi seharusnya penyuluhan dalam kerangka modernisasi pertanian hadir sebagai proses rasionalisasi bagi petani karena pada dasarnya petani juga memiliki rasionalisasinya sendiri. Sehingga modernisasi dengan revolusi hijaunya hadir sebagai sebuah proses panjang untuk memberikan kesempatan kepada petani mengenai apa, kenapa, dan bagaimana sebauh inovasi pertanian itu ada.

Penyuluh pertanian ketika memiliki inovasi atau informasi baru maka tidak serta merta menyebarkannya kepada petani, namun mereka melakukan diplomasi terlebih dahulu kepada petani kaya, ketua kelompok tani, atau orang yang 
dianggap terhormat. Padahal hal ini menurut pendapat Jamal (2009) sistem panutan dalampembangunan pedesaan merupakan sesuatu yang tidak berdasar. Lebih lanjut Widodo (2009) menjelaskan bahwa di era modernisasi pengambilan keputusan bersama sangat didominasi oleh kekuatan pemimpn kelembagaan modern desa. Tidak ada kepercayaan dari penyuluh kepada petani secara langsung, akibatnya petani juga selalu merasa dirinya adalah kaum kecil yang bodoh.Akibatnya adalah masyarakat tani tidak memiliki ruang untuk menyuarakan kebutuhannya. Pemerintah memposisikan diri sebagai pihak yang serba tahu akan keinginan dan kebutuhan petani. Petani tidak memiliki kesempatan untuk menentukan sendiri kegiatan pertanian yang akan diambil karena memang pemerintah hanya memfokuskan petani untuk menanam satu komoditas saja.

Penyuluhan pertanian tidak lagi berbasis pada proses belajar melainkan pada proses pemaksaan untuk menggunakan teknologi tertentu demi tercapainya tujuan tunggal pemerintah.Masyarakat desa sering kali diposisikan sebagai pihak yang digerakkan untuk mendukung pembangunan yang direncanakan dan dilaksanakan pemerintah tanpa dimintapendapatnya (Jamal, 2009). Tujuan masyarakat tanipun diabaikan karena yang menjadi fokus adalah tujuan nasional bukan untuk tujuan kemakmuran petani. Padahal dalam hemat Rhoades dan Bebbington (1995) serta Arce dan Long (1992) penduduk setempat sebenarnya adalah pencipta dari solusi-solusi yang dihasilkannya sendiri dalam menghadapi berbagai tantangan dan masalah yang timbul akibat pengalaman sehari-hari. Petani tidak selalu identik dengan kelompok yang bodoh, pasif, dan tidak memiliki inisiatif. Penyuluhan hanya membantu penduduk setempat tersebut untuk menciptakan solusi bukan sebagai pihak yang memberi solusi.

Bahkan efeknya terasa sampai hari ini, ketika desentralisasi diberlakukan pemerintah daerah masih kebingungan menentukan prioritas pembangunan pertaniannya. Kegiatan penyuluhan juga semacam kehilangan arah, tidak mampu lagi mempengaruhi petani untuk menerapkan suatu inovasi. Penyuluh yang dahulu sangat powerfull hari ini menjadi tidak berdaya karena memang sudah terbiasa dengan sistem. Dengan sistem top down, penyuluh selalu diuntungkan karena tidak perlu memikirkan rencana penyuluhan sehingga penyuluh juga kurang mengembangkan kapasitas dirinya. Sedangkan ketika hari ini sudut pandang penyuluhan menjadi bottom up, penyuluh tidak mampu beradaptasi dan yang etrjadi adalah penyuluh semakin ditinggalkan oleh petani karena dirasa gagal dalam menyediakan informasi bagi mereka.Keberadaan wanita tani pada saat itu hanyalah sebagai objek pembangunan. Walaupun demikian, dalam pelaksanaannya wanita tani tetap melaksanakan apa yang diperintahkan, tekun mengerjakan dan mengharapkan panen sesuai yang diharapkan. Kondisi semacam ini menyebabkan ketergantungan masyarakat tani kepada kebijakan pemerintah dan penyuluh sangat tinggi (Umar, 2007 dalam Ekasari et. al. 2014) 


Selama ini, $\begin{array}{r}\text { penyuluhan } \\ \text { bertujuan }\end{array}$
pertanian bukan hanya memberikan
mengembangkan kapasitas petani
namun memada petani. Akibatnya
sumbangan kepada
petani menjadi tergantung dan ketika
diberi dana untuk berdaya mereka
tidak mampu menggunakannya
karena mereka juga tidak bisa
mengidentifikasi masalah serta
potensi yang dimiliki. Bahkan, karena rendahnya penguatan kapasitas petani menyebabkan kreativitas dan kearifan lembaga-lembaga lokal tidak berkembang bahkan banyak yang hilang. Petani sekarang hanya menunggu karena tidak mengetahui apa yang seharusnya dilakukan. Petani menjadi lebih suka mendapatkan instruksi yang jelas dan diberi arahan untuk mencapai target apa daripada harus memikirkan dirinya sendiri.Seharusnya yang terlintas pertama kali dalam pemikiran pemerintah adalah mengenai konsepsi apa yang sebenarnya harus dilakukan dengan berkaca pada kebutuhan serta pengetahuan yang dimiliki oleh masyarakat tani.

Menurut Zamroni (2010), akibat revolusi hijau adalah para petani konvensional lebih banyak berpikir dalam jangka pendek dan praktis, yakni meningkatkan produktivitas dan meningkatkan kesejahteraan sesaat tanpa mempertimbangkan aspek keberlanjutan kehidupan sebagai petani yang sangat bergantung pada kemurahan alam. Singkatnya, revolusi hijau menyebabkan marginalisasi sistemikdi dunia pertanian. Marginalisasi sistemik diartikan sebagai suatu kondisi yang mengakibatkan semakin melemahnya kehidupan petani dan semakin tereduksinya kemandirian petani akibat intervensi yang keliru atau tidak memikirkan jangka panjang.

\section{Teknologi Informasi yang Bias Fungsi}

Beralih ke bahasan mengenai pemanfaatan teknologi informasi. Tidak bisa dipungkiri jika modernisasi yang terjadi dominan dalam hal peningkatan teknologi.Tingkat pendidikan petani yang masih rendah dalam hal ini bisa membuat masyarakat tani"dimanfaatkan" teknologi bukan memanfaatkanya. Petani saat ini juga sudah akrab dengan penggunaan gawai, namun fenomena ini justru ikut memiliki andil dalam perubahan sosial yang terjadi di masyarakat tani. Petani menjadi lebih acuh kepada lingkungan sosialnya karena menurut Zulkarnain et. al. (2016) pada awalnya gawai memiliki fungsi sebagai alat komunikasi yang bersifat darurat atau sporadis kemudian bergeser menjadi rutin, selain itu mengubah tindakan yang awalnya semata instrumental menjadi ekspresi komunikasi yang beragam hingga yang terparah adalah menjauhkan seseorang dari lingkungan sosialnya sendiri.

Tradisi yang melekat pada masyarakat perdesaanpun lambat laun hilang, sistem gotong royong, musyawarah, hingga keramahtamahan telah berganti menjadi wajah yang individualistik.Perkembangan

teknologi telah menyebabkan berkurangnya frekuensi individu untuk saling bertatap muka. Hilangnya gotong royong menyebabkan masyarakat lebih bersifat individualis dan kurang mempunyai rasa solidaritas di antara sesamanya lagi (Sunarya et. al., 2016). 
Munculnya gawai menyebabkan petani lebih suka mencari informasi dari internet karena semuanya sudah tersedia dengan mudah. Dampaknya jelas yaitu matinya kegiatan peyuluhan hingga melemahnya relasi sosial diantara petani itu sendiri. Satu sisi memang modernisasi di bidang teknologi informasi memudahkan petani karena terdapat transparansi informasi namun menurut Bryant (2007) teknologi ini juga dinilai tidak seirama dengan model interaksi individu di perdesaan yang bersifat langsung dan mekanis. Petani yag dahulu sering bertatap muka untuk berkomunikasi kini semakin termediasi. Bukti nyatanya adalah penelitian dari Zulkarnain et. al. (2016) dan Mulyadi (2015) di Kabupaten Bogor dan Kota Makassar yang menyebutkan bahwa penduduk di kawasan perdesaan kini sudah jarang berkomunikasi dan bersosialisasi secara langsung, sekalipun dengan keluarganya sendiri bahkan ada yang sampai di titik ekstrem yaitu membuat mereka dijauhi oleh komunitasnya.

\section{Kegagalan Regenerasi Petani}

Mulyadi (2015) dalam

penelitiannya juga menemukan suatu fenomena bahwa modernisasi memiliki andil dalam kegagalan regenerasi petani di Indonesia. Industrialisasi bahkan telah memicu konflik kepemilikan lahan antara petani dengan investor hingga antar petani itu sendiri. Industrialisasi sebagai produk dari modernisasi menjadikan pemuda desa lebih memilih meninggalkan kampung halamannya. Bekerja menjadi petani tidak lagi menarik bagi pemuda desa.Pemuda desa menganggap bahwa profesi sebagai petani tidak menjamin finansial di masa depan. Keengganan menjadi seorang petani mewabah di kalangan pemuda Indonesia. Hal ini terbukti bahwa di jaman yang modern ini banyak anak muda alergi untuk menjadi seorang petani. Bahkan lulusan fakultas pertanian sekalipun menghindari jadi petani. Mereka tidak tertarik berpanas-panasan di lahan, tak suka kotor, justru lebih nyaman bekerja di kantor dan berkutat di depan komputer. Menjadi seorang petani harus siap mengambil resiko yang besar untuk untung yang besar pula. Istilahnya high risk,high revenue. Pemuda saat ini enggan mengambil resiko. Lebih memilih berjalan di zona nyaman dan tinggal menunggu gaji. Akibatnya adalah kekurangan tenaga kerja di sektor pertanian. Masalah seperti ini merupakan tembok terbesar yang harus dihancurkan Pemerintah. Bagaimana caranya meningkatkan kembali minat dan semangat generasi muda untuk menjadi petani. Namun, disitasi dari Sutrisna (2008) masalah lain kemudian muncul yaitu pemuda desa yang keterampilannya terbatas kemudian ditolak oleh sistem industrialisasi. Mereka juga sulit kembali ke desa untuk menjadi petani karena hilangnya sebagian besar kawasan pertanian sebagai akibat perluasan industri. Hal ini mengakibatkan banyaknya pemuda desa yang menganggur, lalu terjebak dalam kriminalitas dan pergaulan bebas serta narkoba. Pastinya semakin menambah beban negara.

Dapat dipahami regenerasi petani menjadi terhambat karena minimnya lahan yang dimiliki. Modernisasi mendorong lahirnya praktik industrialisasi dan komersialisasi atas lahan pertanian 
setiap tahun semakin marak yang dilakukan oleh kaum pemodal besar melalui investasi. Akibatnya terjadi alih fungsi lahan yang pada akhirnya menjadikan luasan lahan pertanian menjadi semakin sempit (Mulyadi, 2015). Masalah akses lahan ini bahkan kerap menjadi sumber konflik antar petani maupun petani dengan industri (Ariendi dan Kinseng, 2011). Industri yang dibangun di suatu daerah dengan menggusur banyak ladang pertanian menurut Widiansyah (2017) akan merubah mata pencaharian penduduknya, sehingga sedikit yang mau menjadi petani. Kesalahan ini sudah lama terjadi sejak era orde baru karena tidak meletakkan masalah pertanahan sebagai basis pembangunan (Wiradi, 2000).

\section{KESIMPULAN DAN SARAN}

Modernisasi dan pembangunan pertanian hadir sebagai sebuah perangkap yang penuh dengan janji manis, janji itu bernama revolusi hijau. Revolusi hijau dengan cita-cita merubah pola pikir petani justru salah dimaknai oleh pemerintah. Pemerintah hanya mengkonsepkan pembangunan pertanian sebagai pembangunan infrastruktur dan mekanisasi pertanian. Langkah pemerintah yang abai terhadap kebutuhan dan kondisi masyarakat menyebabkan banyak terjadi perubahan sosial budaya bahkan hingga ekonomi di struktur kehidupan masyarakat desa. Banyak wanita tani yang kehilangan pekerjaan dan termarginalisasi, tidak ada lagi pembagian kerja berdasarkan gender, kencangnya laju urbanisasi, mandeknya regenerasi, ketergantungan terhadap industri, musnahnya plasma nutfah, hilangnya budaya gotong royong, lahirnya sistem kasta dalam masyarakat tani, melemahnya fungsi kelembagaan lokal, petani hanya sebagai objek penyuluhan, dan lainnya.

Karena berbagai dampak negatif yang muncul inilah kemudian muncul suatu pemikiran akan pentingnya reformulasi konsep modernisasi di sektor pertanian. Kedepan modernisasi pertanian harus berbasis pada komunitas tani dan meletakkan perspektif pembangunan pedesaan secara utuh meliputi sektor primer, sektor sekunder (sektor komplemen) dan sektor tersier (jasa). Modernisasi pertanian sebaiknya direncanakan, dikelola, dan dikendalikan sehingga seiring dan kondusif dengan pembangunan pertanian. Mengingat bahwa tujuan dari setiap tahap pembangunan adalah untuk meningkatkan taraf hidup kesejahteraan masyarakat. Pada akhirnya, proses pembangunan pertanian ke depan harus menggunakan pendekatan pemberdayaan dengan tujuan fungsional lebih menyeluruh dan terpadu untuk pembangunan manusia seutuhnya. Pembangunan dengan pendekatan pemberdayaan harus mampu membangun fisik dan non-fisik, menyangkut sumber daya alam (SDA), sumber daya lingkungan (SDL) dan sumber daya manusia (SDM). Jadi, diharapkan terminimalisirnya dampak negatif yang terjadi sehingga kehidupan sosial dan ekonomi masyarakat lambat laun akan membaik.

\section{DAFTAR PUSTAKA}

Arce, A. dan N. Long. 1992. The Dynamics of Knowledge: Interfaces between Bureaucrats 
and Peasants. London: Routledge.

Ariendi, G. T., dan Kinseng, R. A. 2011. Strategi Perjuangan Petani dalam Mendapatkan Akses dan Penguasaan atas Lahan. Sodality: Jurnal Transdisiplin Sosiologi, Komunikasi, dan Ekologi Manusia 5(1): 13-31.

Bryant, C. dan Peck, D. L. 2007.21st Century Sociology: A Reference Handbook. California-LondonNew Delhi:Sage Publication.

Djoh, D. A. 2018. Dampak Modernisasi Terhadap Perubahan Sosial Masyarakat Tani Di Desa Kambata Tana Kabupaten Sumba Timur. Jurnal Ekonomi Pertanian dan Agribisnis (JEPA) 2(4): 332-339.

Ekasari, K., M.Saleh S. Ali, Darmawan Salman, Akhsan dan A. Kasirang. 2014. Konflik Komunikasi Dalam Penyuluhan Pertanian Di Kabupaten Maros Provinsi Sulawesi Selatan. Jurnal Ilmu Komunikasi 12(1): 85-97.

Elizabeth, R. 2007. Fenomena Sosiologis Metamorphosis Petani: Ke Arah Keberpihakan Pada Masyarakat Petani Di Pedesaan Yang Terpinggirkan Terkait Konsep Ekonomi Kerakyatan. Forum Penelitian Agro Ekonomi 25(1): 29-42.

Elizabeth, R. 2007. Pemberdayaan Wanita Mendukung Strategi GenderMainstreaming Dalam Kebijakan Pembangunan PertanianDi Perdesaan.Forum Penelitian Agro Ekonomi 25(2): 126-135.
Fakih, M. 1999. Analisis Gender dan Transformasi Sosial. Yogyakarta: Penerbit Pustaka Pelajar.

FAO. 2011. The State of Food Insecurity in the World 2011. Rome: Food and Agriculture Organization of the United Nations.

Hendrastomo, G. 2011. Keterpurukan Sektor Pertanian Sebagai Potret Kegagalan Industrialisasi Di Indonesia. Dimensia 5(1): 83

Husken, F. 1988. Masyarakat Desa dalam Perubahan Zaman: Sejarah Differensiasi Sosial di Jawa 1830-1980. Jakarta: Grasindo.

Ismanto, K. Huda, H. M., dan Maulida, C. 2012. Transformasi Masyarakat Petani Mranggen Menuju Masyarakat Industri. Jurnal Penelitian 9(1): 35-48.

Jamal, E. 2009. Membangun Momentum Baru Pembangunan Pedesaan di Indonesia. Jurnal Litbang Pertanian 28(1): 7-14.

Kandar, I. R. 2014. Kondisi Sosial Ekonomi Masyarakat GunungkidulMasa Revolusi Hijau (1970-1974). Skripsi. Yogyakarta: Program Studi Pendidikan Sejarah, Jurusan Pendidikan Sejarah, Fakultas Ilmu Sosial, Universitas Negeri Yogyakarta.

Ketetapan Majelis Permusyawaratan Rakyat No.IV/MPR/1999 tentang Garis Besar Haluan Negara.

Koentjaraningrat. 2000. Kebudayaan Mentalitas dan Pembangunan. 
Jakarta: PT Gramedia Pustaka Utama.

Lan, T. J. 2015. Perempuan dan Modernisasi. Jurnal Masyarakat \& Budaya 17(1): 17-28.

Mulyadi, M. 2015. Perubahan Sosial Masyarakat Agraris Ke Masyarakat Industri Dalam Pembangunan Masyarakat Di Kecamatan Tamalate Kota Makassar. Jurnal Bina Praja 7(4): 311-322.

Nurpilihan, Handarto dan Nurjanah, S. 2000. Dampak Sosial Modernisasi Pertanian Terhadap Peranan Wanita Pedesaan Di Kabupaten Bandung.Jurnal

Sosiohumaniora 2(3): $72-80$.

Pretty, J. N. 1995. Regenerating Agriculture: Policies and Practice for Sustainability and Self-Reliance. London: Earthscan Publication Ltd.

Robert H. L. 2001. Perspektif Tentang Perubahan Sosial. Jakarta: PenerbitRineka Cipta.

Rhoades, R.E dan A. Bebbington. 1995. Farmers Who Experiment: an Untapped Resource for Agricultural Research and Development. London: Intermediate Technology Publications.

Rifkian, B. E., Suharso, P. dan Sukidin. 2017. Modernisasi Pertanian (Studi Kasus Tentang Peluang Kerja Dan Pendapatan Petani Dalam Sistem Pertanian Di Desa Dukuhdempok Kecamatan Wuluhan
Kabupaten Jember). Jurnal Pendidikan Ekonomi: Jurnal Ilmiah Ilmu Pendidikan, Ilmu Ekonomi, dan Ilmu Sosial 11(1): 39-48.

Soetrisno, L. 1990. Peranan Wanita Dalam Pembangunan: Suatu Perspektif Sosiologis. Populasi 1(1): 13-21.

Stads, G.J., Haryono, Nurjayanti S. 2007. Agricultural R\&D in Indonesia: Policy Investment and Institutional Profile. Agricultural Science and Technology Indicators (ASTI) Country Report. International Food Policy Research Institute (IFPRI) and Indonesian Agency for Agricultural Research and Development (IAARD).

Stompka, P. 2007. Sosiologi Perubahan Sosial. Jakarta: Prenada Media Group.

Sunarya, S., Supriyanto, dan Hudaidah. 2016. Perubahan Sosial Di Air Belo Kecamatan Muntok Kabupaten Bangka Barat (2000-2007). Jurnal Criksetra 5(9): 25-37.

Suseno, D. dan Suyatna, H. 2007. Mewujudkan Kebijakan Pertanian yang Pro-Petani. Jurnal Ilmu Sosial dan Ilmu Politik 10(3): 267-294.

Sutrisna, E. 2008. Dampak Industrialisasi Terhadap Aspek Sosial Ekonomi Masyarakat. Jurnal Industri dan Perkotaan 12(22): 1743-1753.

Tahir, T. 2009. Modernisasi Dan Pengaruhnya Terhadap Kehidupan Sosial Masyarakat 
Petani Padi Sawah Di Desa Mojong Kabupaten Sidenreng Rappang. Jurnal Pionir 8(7): 112.

Thirtle C, Lin L, Piesse J. 2013. The Impact of Research-Led Agricultural Productivity Growth on Poverty Reduction in Africa, Asia and Latin America. World Dev.31:1959-1975.

Tjondronegoro, S.M.P. 1999. Revolusi Hijau dan Perubahan Sosial di Pedesaan Jawa. Jakarta: Direktorat Jenderal Pendidikan Tinggi, Departemen Pendidikan dan Kebudayaan RI.

Usman, S. 2004. Jalan Terjal Perubahan Sosial. Yogyakarta: CIRED.

Usman, S. 2015. Esai-esai Sosiologi: Perubahan Sosial. Yogyakarta:Pustaka Pelajar.

Widiansyah, S. 2017. Dampak Keberadaan Industri terhadap Perubahan Struktur Sosial Masyarakat (Studi masyarakat Desa Bojong, Cikupa, Kabupaten Tangerang). Jurnal Hermeneutika 3(2): 35-46.
Widodo, S. 2009. Proses Transformasi Pertanian Dan Perubahan Sosial Pada Masyarakat Samin Di Bojonegoro. Jurnal Embryo 6(1): 57-66.

Wik M, Pingali P, Broca S. 2008. Background Paper for the World Development Report 2008: Global Agricultural Performance: Past Trends and Future Prospects. Washington, DC: World Bank.

Wiradi, G. 2000. Reforma Agraria, Perjalanan yang Belum Berakhir. Yogyakarta: Pustaka Pelajar.

Zamroni, M. I. 2010. Perubahan Sosial-Budaya Petani Organik Di Yogyakarta. Jurnal Masyarakat \& Budaya 12(1): 71-92.

Zulkarnain, I., Husaini, Baekhaki, K., dan Christian, F. Y. 2016. Relasi Antara Penggunaan Android dan Perubahan Sosial Perdesaan: Studi Perubahan Sosial di Kabupaten Bogor Jawa Barat. Jurnal Society 6(2): 1-14. 